\title{
Spolupráce VÚV TGM, v. v. i., a státních podniků Povodí v rámci Radiační monitorovací sítě ČR
}

\section{DIANA MAREŠOVÁ, BARBORA SEDLÁŘOVÁ, EDUARD HANSLÍK, EVA JURANOVÁ}

Klíčová slova: Radiační monitorovací sít - radionuklidy - povrchová voda - pitná voda - sedimenty

\section{SOUHRN}

Článek uvádí přehled základních právních předpisů upravujících činnost Výzkumného ústavu vodohospodářského T. G. Masaryka, v. v. i., a jednotlivých Povodí, státní podnik, v rámci Radiační monitorovací sítě ČR. Je uveden přehled sledovaných profilů a požadavky na četnost odběru vzorků, hodnocených ukazatelů a dále výsledky monitorování za období 2004-2016.

\section{ÚVOD}

Pravidelné sledování radiační situace bylo zahájeno v dubnu 1986 těsně před havárií v jaderné elektrárně v Černobylu, kdy byla zřízena Radiační monitorovací sít. Proces systematického zajištování činnosti a vybavení Celostátní radiační monitorovací sítě (RMS) v současné podobě požadované evropskou legislativou byl zahájen přijetím usnesení vlády č. 478 ze dne 14.7.2001. Právní základ pro činnost RMS byl príijat v roce 2002 novelizací atomového zákona č. 18/1997 Sb. (zákon Č. 13/2002 Sb.) [1] a vyhláškou SúJB č. 319/2002 Sb. [2]. V minulém roce proběhla významná změna legislativy - byl vydán nový atomový zákon č. 263/2016 Sb. [3] a vyhláška SÚJB č. 360/2016 Sb., o monitorování radiační situace [4].

Výzkumný ústav vodohospodářský T. G. Masaryka, v. v. i. (dále jen VúV TGM), se ve spolupráci se státními podniky Povodí podílí na monitorování radiační situace na území České republiky, které zajištuju Státní úřad pro jadernou bezpečnost (dále jen SúJB) od roku 2004. V Referenční laboratoři složek životního prostředí a odpadů VúV TGM jsou sledovány radioaktivní látky v povrchových a pitných vodách, sedimentech, rybách a vodárenských kalech.

\section{METODIKA}

Do monitoringu byly vybrány lokality tak, aby byly do spolupráce zapojeny všechny podniky Povodí a bylo zajištěno rovnoměrné rozložení profilů po celé České republice. Jedná se o tři závěrové profily na hlavních tocích (LabeHřensko, Odra-Bohumín a Morava-Moravský Sv. Ján) a sedm profilů na vodních nádržích (VN Švihov, VN Římov, VN Fláje, VN Přísečnice, VN Křižanovice, VN Vír, VN Kružberk) a dále profil Praha-Podolí, kde je sledována objemová aktivita tritia s vyšší četností. Upravená pitná voda je sledována z vybraných pěti nádrží. Přehled odběrových míst je na obr. 1.

Monitorování je prováděno formou normálního monitorování za obvyklé radiační situace a formou havarijního monitorování za nehodové expoziční situace. Za obvyklé radiační situace jsou odebírány na jednotlivých profilech vzorky vod s četností $4 \times$ ročně. Jsou sledovány ukazatele obsahu radioaktivních látek v povrchových vodách (celková objemová aktivita beta po odečtení př́spěvku draslíku 40, objemová aktivita tritia, objemová aktivita stroncia 90 a objemová aktivita cezia 137), ve dnových sedimentech (hmotnostní aktivita cezia 137), v biomase ryb (hmotnostní aktivita cezia 137) a v pitných vodách (objemová aktivita tritia, objemová aktivita stroncia 90 a objemová aktivita cezia 137) a kalech z úpravy vody (hmotnostní aktivita cezia 137). Stanovení objemové aktivity cezia 137 a stroncia 90 je prováděno ze vzorků vody o objemu 20 I, stanovení postihuje tyto radionuklidy ve veškerých látkách. Stanovení v pevných matricích je prováděno jedenkrát ročně, a to v sušině $\left(105^{\circ} \mathrm{C}\right)$. V prípadě ryb je výsledná hmotnostní aktivita cezia 137 vztažena na čerstvou hmotnost. Odběr, předúpravu vzorků a stanovení ukazatele celkové objemové aktivity beta provádí jednotlivá Povodí, s. p., stanovení ostatních ukazatelů (tritia, cezia 137 a stroncia 90) provádí Referenční laboratoř složek životního prostředí a odpadů VÚV TGM.

Jsou uváděny výsledky větší než nejmenší významná aktivita $\left(\mathrm{c}_{\mathrm{NV}}\right)$. Hodnoty $<\mathrm{C}_{\mathrm{NV}}$ byly do průměrných hodnot (aritmetický průměr) započteny na úrovni $\mathrm{C}_{\mathrm{NV}}$.

Získávaná data jsou předávána do informačního systému RMS (MonRaS). Jejich zveřejňování zajištuje SÚJB v současnosti prostřednictvím webových stránek. V letech 2004 a 2005 byly výsledky zveřejněny ve Zprávě o radiační situaci na území České republiky, od roku 2006 jsou výsledky součástí výročních zpráv SúJB.

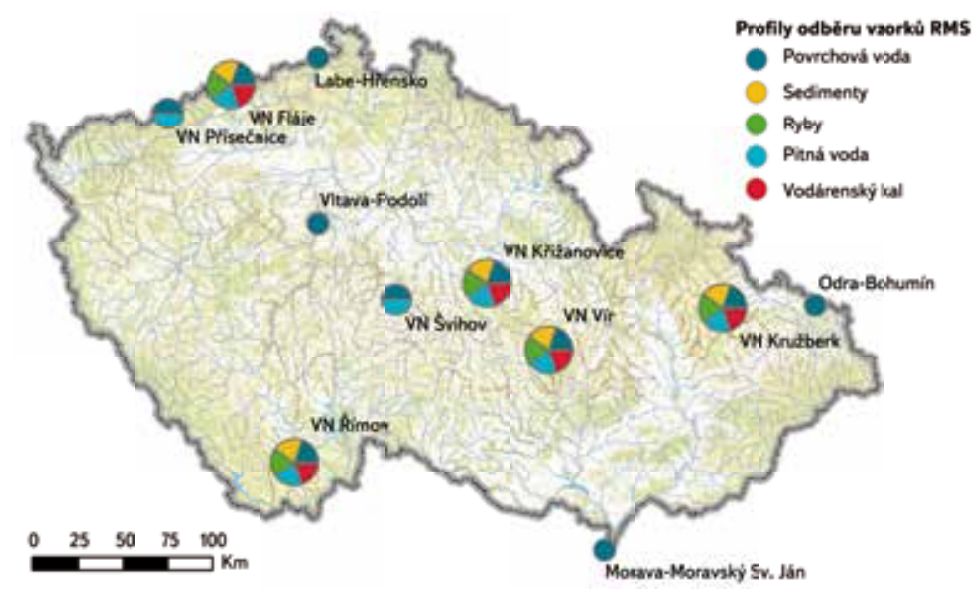

Obr. 1. Mapa odběrových míst Fig. 1. Map of sampling sites 


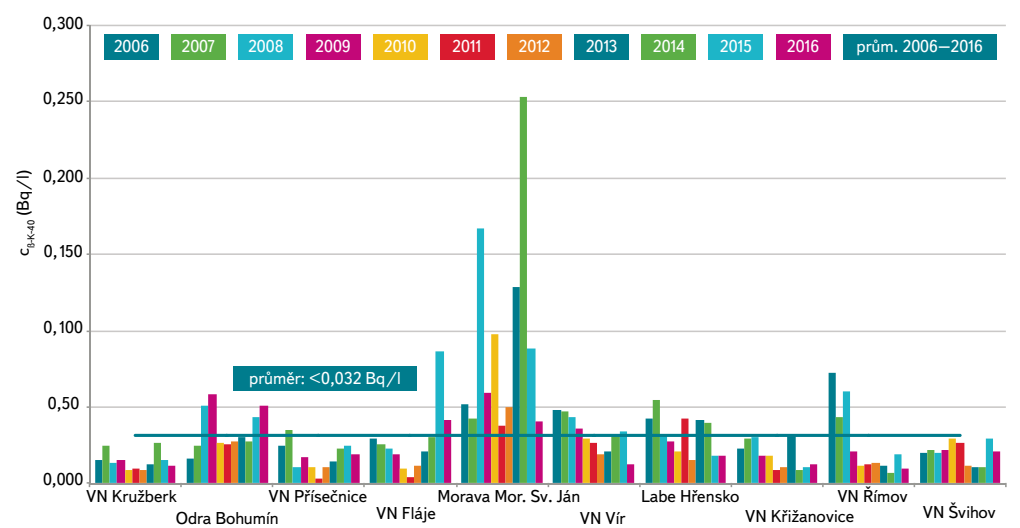

Obr. 2. Vývoj ročních průměrných celkových objemových aktivit beta po odečtení príspěvku ${ }^{40} \mathrm{~K}\left(\mathrm{C}_{\beta K-40}\right)$ v povrchových vodách

Fig. 2. Development of annual average gross beta activity $\left(\mathrm{C}_{\beta K-40}\right)$ in surface water

\section{VÝSLEDKY A DISKUSE}

Na obr. 2 je zpracován přehled výsledků sledování celkové objemové aktivity beta po odečtení př́spěvku ${ }^{40} \mathrm{~K}$ za období 2006-2016. Průměrná hodnota vyhodnocená ze všech profilů za toto období byla méně než 0,032 Bq/I. Ve sledovaném období nebyly zaznamenány žádné extrémní hodnoty.

Toto stanovení provádí laboratoře státních podniků Povodí podle ČSN 757612 [5]. Jedná se o screeningový ukazatel. Jedná se o ukazatel možného obsahu radionuklidů s preměnou beta. Zjištěná hodnota postihuje zejména radionuklidy vysílající záření beta, a to různou měrou, některé nepostihuje vůbec. Slouží zejména jako podklad k rozhodování o potřebě stanovení objemových aktivit jednotlivých radionuklidů ve vodě. Za obvyklé radiační situace charakterizuje zejména úroveň prírodního pozadí. Za havarijní situace by sloužil k rychlé klasifikaci kontaminace vzorků z odběrových míst. Pro tyto účely byla ve spolupráci se Státním ústavem pro radiační ochranu zavedena metoda rychlého stanovení celkové objemové aktivity beta pro účely havarijního monitorování (ČSN 75 7613) [6].

Ostatní stanovení, tj. stanovení tritia, cezia 137 a stroncia 90, provádí vzhledem k nárokům na prístrojové vybavení (kapalinová scintilační spektrometrie, gamaspektrometrie) a časovou náročnost (radiochemická separace) Referenční laboratoř složek životního prostředí a odpadů VúV TGM ve vzorcích odebraných laboratořemi státních podniků Povodí, které provádí předúpravu (zakoncentrování velkoobjemových vzorků).

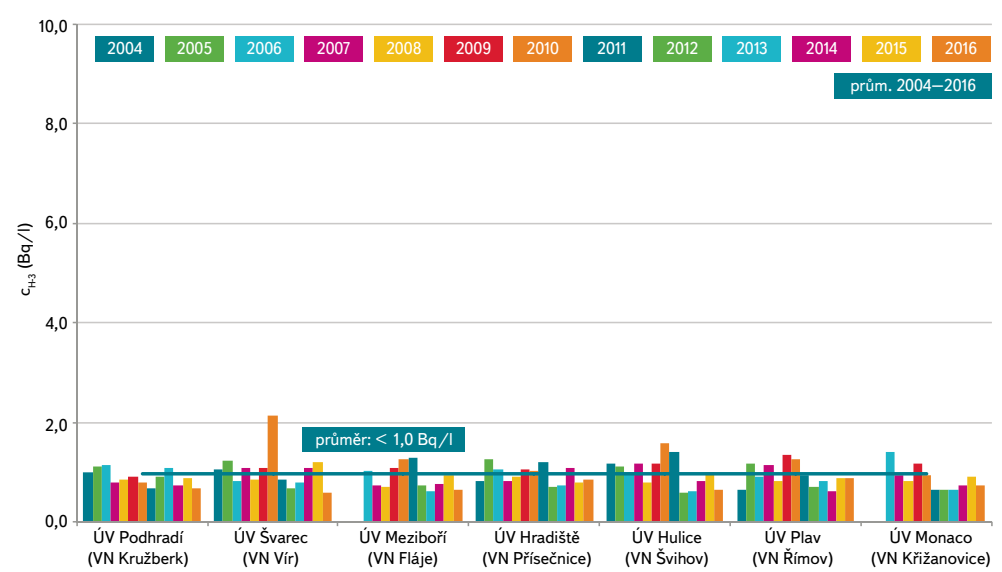

Obr. 3. Vývoj ročních průměrných objemových aktivit tritia $\left(\mathrm{C}_{\mathrm{H}-3_{3}}\right) \vee$ pitných vodách

Fig. 3. Development of annual average tritium activity concentrations $\left(\mathrm{C}_{\mathrm{H}-3}\right)$ in drinking water

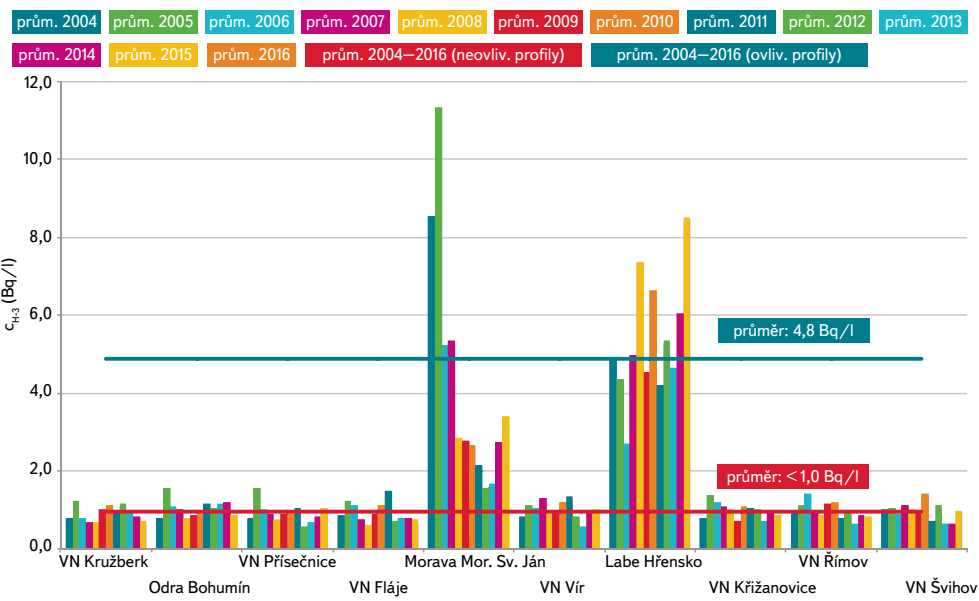

Obr. 4. Vývoj ročních průměrných objemových aktivit tritia $\left(\mathrm{C}_{\mathrm{H}_{-3}}\right) \vee$ povrchových vodách Fig. 4. Development of annual average tritium activity concentrations $\left(\mathrm{C}_{\mathrm{H}-3}\right)$ in surface water

Všechny tyto radionuklidy jsou sledovány zejména v souvislosti s provozem jaderných elektráren nejen na našem území. S výjimkou tritia se jedná o antropogenní radionuklidy, které se do prostředí dostávají v důsledku využívání jaderné energie. Tritium vzniká i přirozenými procesy v atmosféře.

Na obr. 3 a 4 je uveden přehled výsledků sledování tritia $v$ pitných a povrchových vodách sledovaných $v$ rámci RMS včetně vyhodnocených průměrů za celé sledované období. $V$ prípadě tritia byly $\vee$ profilech pod zaústěním odpadních vod z JE Temelín a JE Dukovany zjištěny hodnoty zvýšené oproti ostatním profilům. Zjištěné zvýšení objemové aktivity tritia odpovídá výpočtově odvozeným hodnotám za predpokladu vypouštění tritia na úrovni limitu aktivity, resp. dávky podle povolení vydaných SúJB. Zatímco průměrná objemová aktivita tritia v povrchových vodách neovlivněných výpustmi z jaderných zařízení a v pitných vodách byla za období 2004-2016 < 1,0 Bq/l, na ovlivněných profilech to bylo 4,9 Bq/I (Labe-Hřensko 5,7 Bq//, Morava-Mor. Sv. Ján 4,0 Bq/I). Samostatně je na obr. 5 uveden vývoj objemové aktivity tritia $\mathrm{C}_{\mathrm{H}-3} \mathrm{v}$ profilu Vltava-Praha-Podolí spolu s ročními průměry, průměrem (13,7 Bq/l) za celé sledované období (2006-2016) včetně ročních kapalných výpustí tritia $A_{H-3}$ podle údajů ČEZ, a. S., JETE [7].

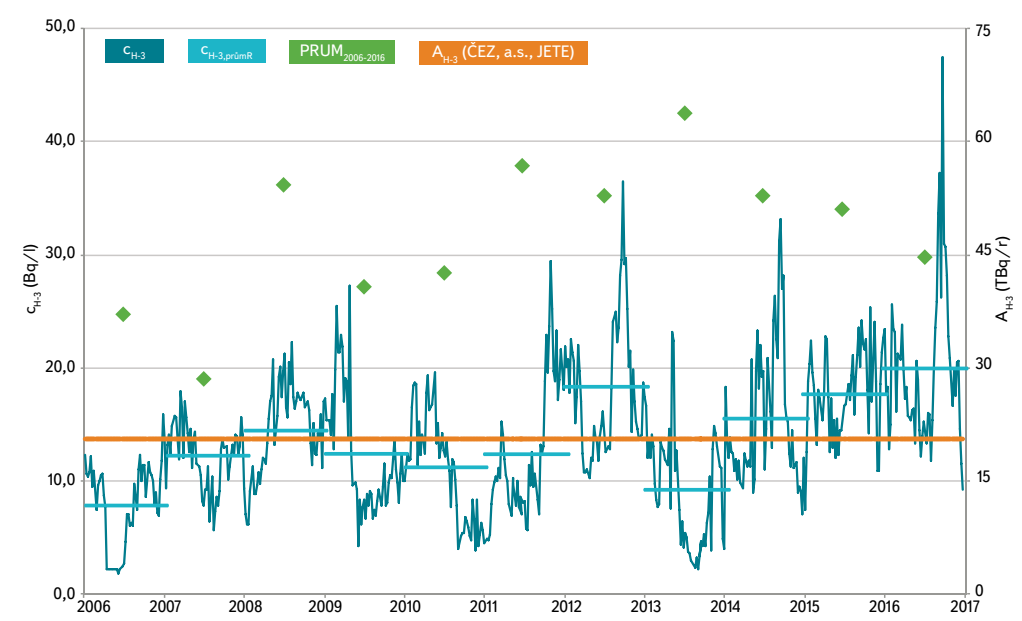

Obr. 5. Vývoj objemové activity tritia $\left(\mathrm{C}_{\mathrm{H}-3}\right)$, ročních průměrných objemových aktivit tritia $\left(c_{H-3, p r u ̛ m R}\right) \vee$ povrchové vodě v Praze-Podolí a ročních kapalných výpustí tritia $\left(A_{H-3}\right)$ podle údajů ČEZ, a. S., JETE [7]

Fig. 5. Development of tritium activity concentration $\left(\mathrm{C}_{\mathrm{H}-3}\right)$, annual average tritium activity concentrations ( $\mathrm{C}_{\mathrm{H}-3, \text { prủmR }}$ ) in surface water in Vltava at Prague Podolí and annual tritium activity in wastewater discharged from NPP Temelín [7] 


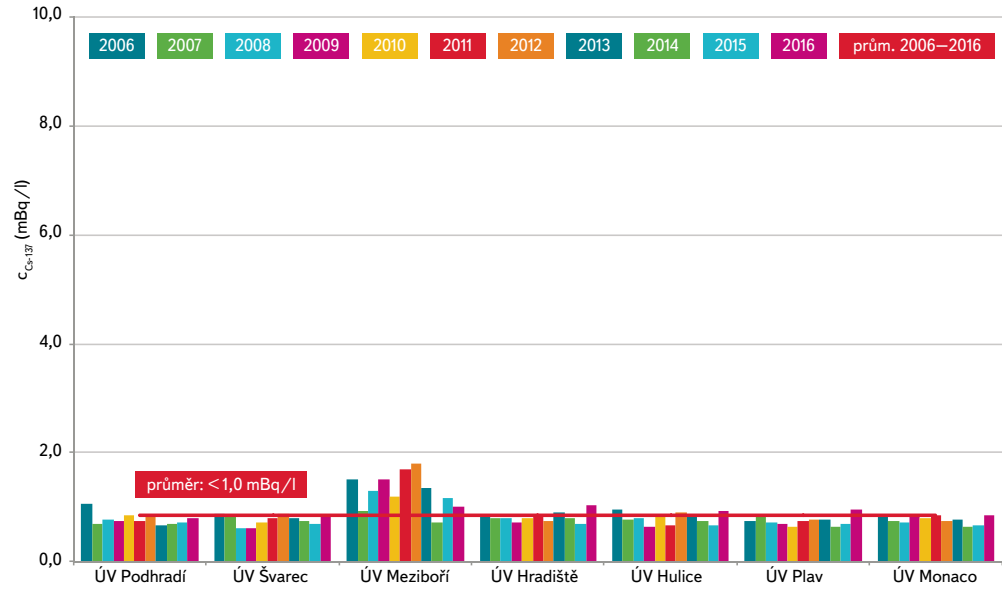

Obr. 6. Vývoj ročních průměrných objemových aktivit cezia $137\left(c_{c c-13}\right)$ v pitných vodách Fig. 6. Development of annual average caesium 137 activity concentrations $\left(c_{[\mathrm{Cs}-137}\right)$ in drinking water

Tento profil je sledován podrobněji, vzorky jsou odebírány 1× týdně. Zjištované aktivity tritia v povrchové vodě odpovídají celkovým výpustem podle údajů provozovatele a splňuji prípustné znečištění povrchových vod podle nařízení vlády 401/2015 Sb., kde je uvedena pro tritium hodnota ročního průměru 1000 Bq/ (při využití povrchové vody jako zdroje pro pitné účely 100 Bq/l) a maxima $3500 \mathrm{~Bq} / \mathrm{l}[8]$

Obsah cezia 137 a stroncia 90 v povrchových i pitných vodách je i při zpracování vzorků o objemu 20 I na hranicích měřitelnosti (většina výsledků je menší než nejmenší významná aktivita) a odpovídá reziduálnímu znečištění po atmosférických testech jaderných zbraní a havárii jaderného reaktoru v Černobylu $\vee$ minulém století. Průměrná koncentrace cezia 137 a stroncia 90 v pitných a povrchových vodách byla za období 2006-2016 <0,001 Bq/l, resp. $<0,003 \mathrm{~Bq} / \mathrm{l}$. Na profilech ovlivněných provozem jaderné elektrárny nebyly zaznamenány žádné zvýšené hodnoty. Výsledky sledování cezia 137 jsou pro ukázku na obr. 6 a 7. Zatímco $v$ prípadě tritia můžeme detekovat prokazatelný vliv našich jaderných elektráren na povrchové vody ovlivněné jejich výpustmi (které splňují požadované limity), v případě cezia 137 a stroncia 90 je teoretický vliv elektráren významně menší než doznívající znečištění umělými radionuklidy z minulého století. Zjištované objemové aktivity jsou o tři rády nižší než hodnoty pro príipustné znečištění - maximum podle NV 401/2015 Sb. (2, resp. 1 Bq/l) a dva řády nižší než je norma environmentální kvality - roční průměr (0,5, resp. 0,2Bq/l) [8].

Cezium 137 v pevných matricích je měřeno spolehlivě (měřené aktivity jsou vyšší než nejmenší významná aktivita). Přehled dosavadních výsledků sledování

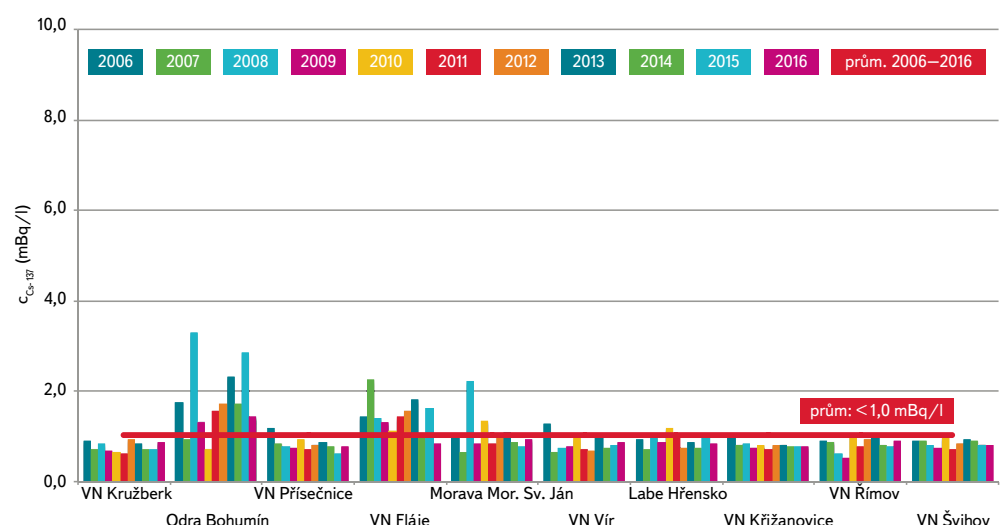

Obr. 7. Vývoj ročních prưměrných objemových aktivit cezia $137\left(c_{C_{s-137}}\right)$ v povrchových vodách Fig. 7. Development of annual average caesium 137 activity concentrations $\left(c_{c_{5-137}}\right)$ in surface water

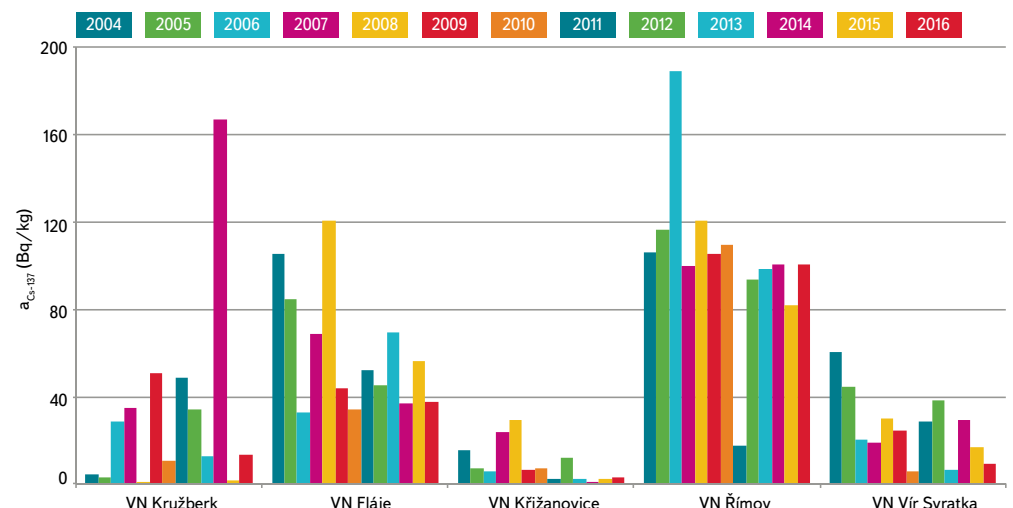

Obr. 8. Vývoj hmotnostních aktivit cezia $137\left(\mathrm{a}_{(\mathrm{cs-137})}\right) \vee$ sedimentech Fig. 8. Development of caesium 137 activity concentrations $\left(a_{c_{s-137}}\right)$ in sediments

cezia 137 v sedimentech je uveden na obr. 8 a v rybách na obr. 9. Nejvyšší hmotnostní aktivita cezia 137 byla zjištěna ve vzorcích sedimentů VN Římov (průměr za období 2004-2016 103 Bq/kg), v rybách VN Fláje (průměr 2004-2016 3,9Bq/kg) a ve vzorcích vodárenských kalů ÚV Švarec a Meziboří (průměr 2004-2016 $9,7 \mathrm{~Bq} / \mathrm{kg}$, resp. 9,6 Bq/kg). I v prípadě pevných matric je hlavním zdrojem cezia 137 reziduální znečištění po atmosférických testech jaderných zbraní a havárii jaderného reaktoru v Černobylu v minulém století.

\section{ZÁVĚR}

Výzkumný ústav vodohospodářský T. G. Masaryka, v. v. i., se od roku 2004 podílí ve spolupráci s podniky Povodí na monitorování radiační situace, které zajištujuje Státní úřad pro jadernou bezpečnost. Laboratoře Povodí, s. p., provádí odběr vzorků a screeningové stanovení celkové objemové aktivity beta. Stanovení dalších ukazatelů obsahu radioaktivních látek - tritia, cesia 137 a stroncia 90 je prováděno ve VúV TGM. Tato spolupráce je významná zejména v kontextu zajištění havarijního monitorování během nehodové expoziční situace. Pro tyto účely jsou Státním úřadem pro jadernou bezpečnost pravidelně pořádána porovnávací měření a zátěžová cvičení v jednotlivých laboratořích.

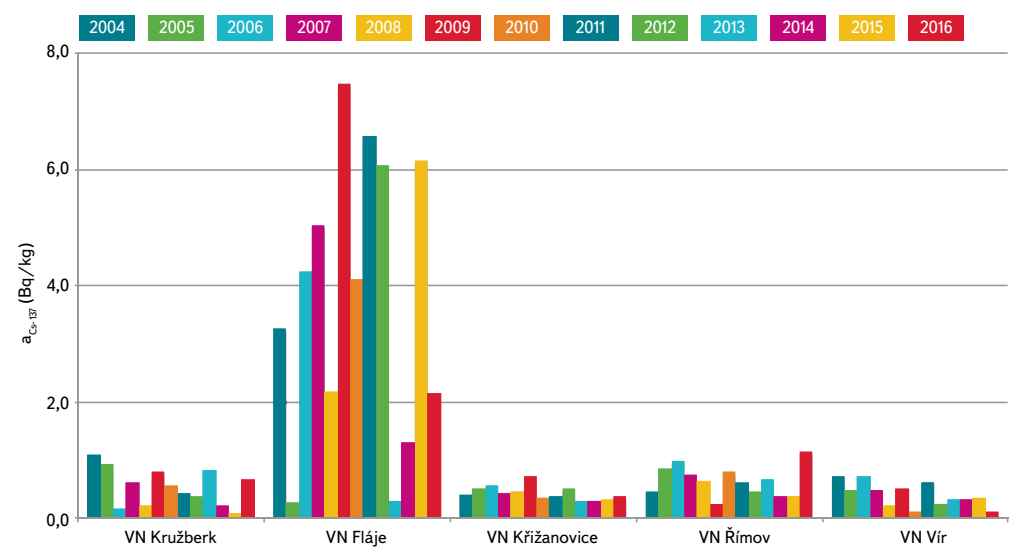

Obr. 9. Vývoj hmotnostních aktivit cezia $137\left(\mathrm{a}_{(\mathrm{Cs}-137}\right)$ v rybách

Fig. 9. Development of caesium 137 activity concentrations $\left(a_{\mathrm{Cs}_{-137}}\right)$ in fish 


\section{Literatura}

[1] Zákon č. 18/1997 Sb., o mírovém využivání jaderné energie a ionizujícího záření (atomový zákon) a o změně a dopInění některých zákonů.

[2] Vyhláška Státního úřadu pro jadernou bezpečnost č. 319/2002 Sb., o funkci a organizaci radiační monitorovací sítě.

[3] Zákon č. 263/2016 Sb., atomový zákon

[4] Vyhláška Státního úřadu pro jadernou bezpečnost č. 360/2016 Sb., o monitorování radiační situace.

[5] ČSN 757612 Jakost vod - Stanovení celkové objemové aktivity beta, ČNI, 2004.

[6] ČSN 757613 Kvalita vod - Rychlá metoda stanovení celkové objemové aktivity beta, ÚNMZ, 2014.

[7] LYSÁČEK, F. a kol. Zpráva o životním prostředí za rok 2006-2016. ČEZ, a. s. Jaderná elektrárna Temelín, 2007-2017

[8] Nařizení vlády 401/2015 Sb., o ukazatelích a hodnotách přípustného znečištění povrchových vod a odpadních vod, náležitostech povolení k vypouštění odpadních vod do vod povrchových a do kanalizací a o citlivých oblastech.

\section{Autoři}

RNDr. Diana Marešová, Ph.D.

凶diana.maresova@vuv.cz

Ing. Barbora Sedlářová

凶barbora.sedlarova@vuv.cz

Ing. Eduard Hanslík

凶eduard.hanslik@vuv.cz

Ing. Eva Juranová1,2

凶eva.juranova@vuv.cz

'Výzkumný ústav vodohospodářský T. G. Masaryka, v. v. i.

2Ústav pro životní prostředí, Přírodovědecká fakulta, Univerzita Karlova

Příspěvěk prošel lektorským řízením.
COOPERATION OF WATER RESEARCH INSTITUTE AND POVODÍ COMPANIES, STATE ENTERPRISE WITHIN THE FRAMEWORK OF RADIATION MONITORING NETWORK OF THE CZECH REPUBLIC

\section{MARESOVA, D. ${ }^{1 ;}$ SEDLAROVA, B. ${ }^{1 ;}$ HANSLIK, E.'; JURANOVA, E. ${ }^{1,2}$}

'TGM Water Research Institute, p. r. i. Institute for Environmental Studies, Faculty of Science, Charles University in Prague

Keywords: radiation monitoring network - radionuclides surface water - drink water - sediments

The paper sums up the legislative framework and cooperation of TGM Water Research Institute and Povodí companies, state enterprises within the framework of radiation monitoring network of the Czech Republic. Further, a summary of monitored items and sampling sites is given. Results from the period 2004-2016 are presented.

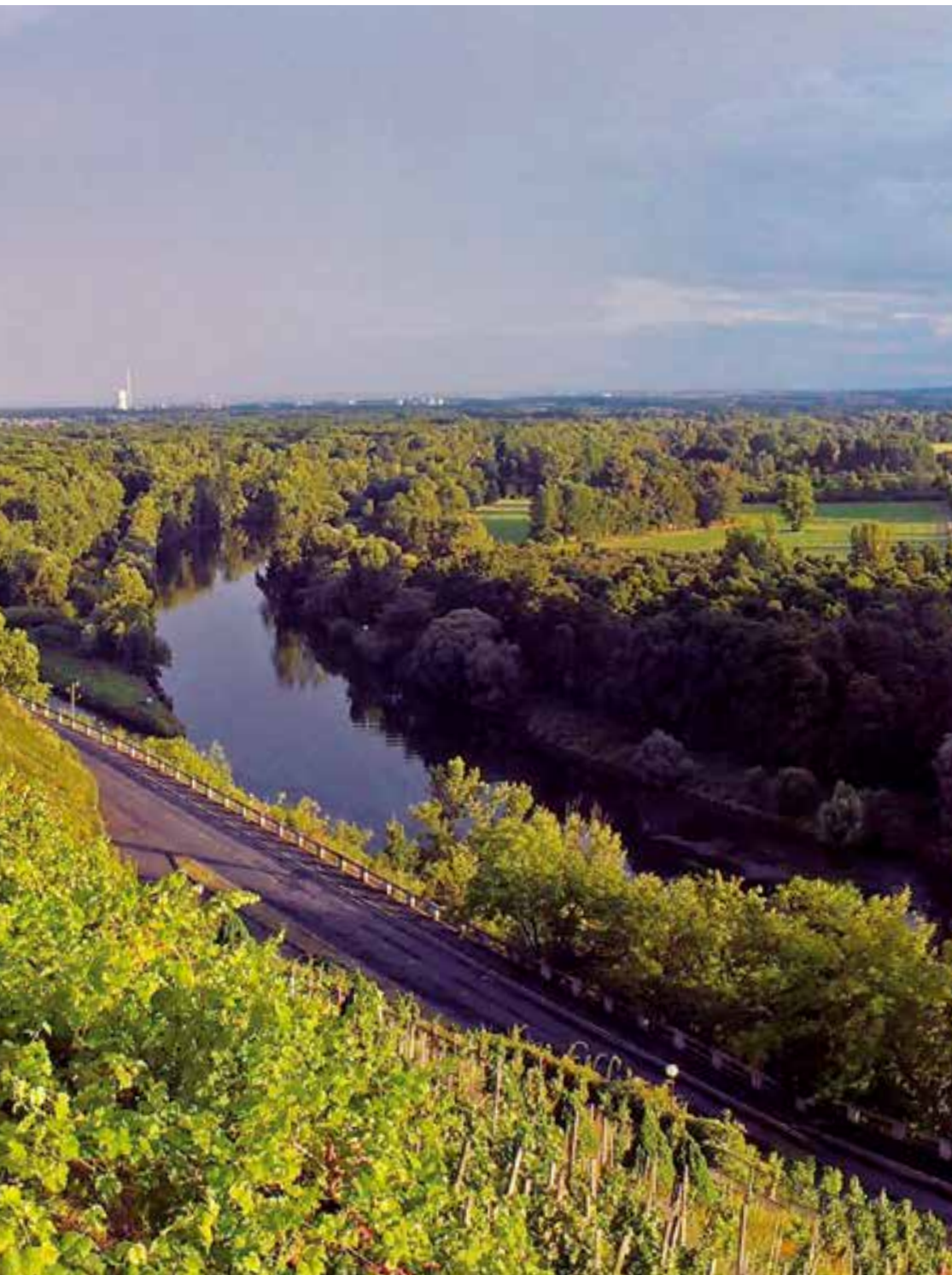

